\title{
Persistent Hyaloid Vessels
}

National Cancer Institute

\section{Source}

National Cancer Institute. Persistent Hyaloid Vessels. NCI Thesaurus. Code C161553.

A cong enital abnormality of the eye caused by failure of regression of the fetal eye vasculature. 